\title{
Growth inhibition of multiresistant enterococci by interferon- $\gamma$-activated human uro-epithelial cells
}

\author{
COLIN R. MACKENZIE, CHRISTIAN HUCKE, DOROTHEE MÜLLER, KERSTIN SEIDEL, OSAMU \\ TAKIKAWA* and WALTER DÄUBENER
}

Institute for Medical Microbiology and Virology, Heinrich-Heine University, Universitätsstraße 1, 40225 Düsseldorf, Germany and *Department of Chemistry and Australian Cataract Research Foundation, University of Wollongong. Northfields Avenue, Wollongong, NSW 2522, Australia

\begin{abstract}
Nosocomial infections with enterococci are an increasing problem in modern medical practice due to the development of resistance to a wide range of antibiotics, including the glycopeptides vancomycin and teicoplanin. An increasing number of vancomycinresistant enterococci (VRE) have been cultured from clinical specimens - especially from patients undergoing immunosuppressive therapy - and bacteraemia caused by these VRE, subsequent to colonisation of epithelial surfaces, is a significant cause of mortality in such patients. Recent evidence showed that the induction of indoleamine 2,3 dioxygenase (IDO) by interferon- $\gamma$ (IFN- $\gamma$ ) inhibited growth of group B streptococci by depleting the essential amino acid L-tryptophan. This study describes the IFN- $\gamma$-induced expression of IDO - shown at a transcriptional level by Northern blot analysis, at translational level by Western blot and also at a functional level by L-tryptophan degradation to L-kynurenine - in the uro-epithelial cell line RT4. The depletion of Ltryptophan resulted in growth inhibition of enterococci, and this was confirmed by abrogation of the inhibitory effect by re-supplementation with excess L-tryptophan. Multiresistant enterococci, including vancomycin-resistant strains resistant to all commercially available antibiotics, were inhibited by the IFN- $\gamma$-induced expression of IDO and subsequent L-tryptophan degradation. This may be an important mechanism in the local restriction of colonisation of the urinary tract by endogenous enterococci and in inhibiting the spread of the bacteria beyond the epithelial barrier.
\end{abstract}

\section{Introduction}

Enterococci, as part of the gut flora, have classically been involved in infections of the urinary tract, wound infections and infections involving contamination by intestinal contents. Enterococci can also cause more serious infections such as infectious endocarditis and with the emergence of multiresistant enterococci (MRE), infections - especially those occurring in immunocompromised patients - carry a greater morbidity [1]. There have been several reports of vancomycin-resistant enterococcal (VRE) species found in immunocompromised patients which are resistant to all available antibiotics and various combinations thereof $[2,3]$. As these multiresistant strains appear to be found in the community [4], possibly as a result of the use of antibiotics in animal feeds $[5,6]$, and as

Received 30 Dec. 1998; revised version received 1 March 1999; accepted 2 March 1999.

Corresponding author: Dr C. R. MacKenzie (e-mail: colin.mackenzie@uni-duesseldorf.de). selection takes place in the hospital setting under broad-spectrum antibiotic therapy [7], it is likely that a certain proportion of patients undergoing immunosuppressive therapy will develop infections due to these organisms. The local containment of infections due to multiresistant organisms may have a significant effect on patient survival, as it has been reported that bacteraemia with VRE is associated with a poorer prognosis in liver transplant patients than bacteraemia with vancomycin-susceptible enterococci [8]. As antibiotic therapy is unable to contain bacterial growth and prevent dissemination of infection by VRE it is of interest to identify immune mechanisms that suppress local bacterial growth. Enterococci, both sensitive and resistant to antibiotics, can be found as part of the normal flora of man and animals, and presumably there is a balance in numbers between multiresistant strains and sensitive strains until selective pressure for resistance, such as broad-spectrum antibiotic therapy, is present. Colonisation of epithelial surfaces and mucous membranes may precede infection, as may be the case in urinary tract infections (UTI). In some 
instances, especially where foreign bodies such as urinary catheters are present, these infections may be asymptomatic. Progression to disseminated infection may take place if unchecked proliferation of bacteria occurs, especially in patients with mucosal and epithelial damage caused by chemotherapy. The innate immune defence exerted at and by the mucosal/epithelial surface is also especially important in leukopenic patients, as the major portion of the immune system is functionally absent.

The L-tryptophan degrading enzyme indoleamine 2,3 dioxygenase (IDO) can be induced by interferon- $\gamma$ (IFN- $\gamma$ ) in human cells [9], and a recent study showed that IFN- $\gamma$-activated human cord blood macrophages inhibited the growth of group B streptococci (GBS) [10]. This antibacterial effect is extracellular and, therefore, also applicable to non-phagocytic cells that are able to respond to IFN- $\gamma$ by induction of IDO expression. As such cells may be found in abundance in the endothelium and muco-epithelial surfaces of the body and can also express large amounts of IDO when stimulated by IFN- $\gamma$, the present study tested the hypothesis that the non-phagocytic, human uro-epithelial cell line RT4 can be stimulated by IFN- $\gamma$ to express IDO and that IFN- $\gamma$-activated RT4 cells are able to inhibit the growth of MRE. It also sought to determine the mechanism involved in this inhibitory effect.

\section{Materials and methods}

\section{Bacteria and culture media}

Bacterial strains were isolated from patient specimens received for diagnostic tests. The year of isolation as well as the site and corresponding clinical data are detailed in Table 1. Ten isolates were obtained from routine stool specimens from otherwise healthy persons. Other isolates were obtained from clinically significant specimens as indicated in Table 1 . The organisms were identified by colony characteristics and agglutination with the Strep Plus diagnostic kit (Oxoid) and identified to species level biochemically (API20STREP, bioMérieux). All bacteria were grown on Brain Heart Infusion Agar (Difco, Hamburg, Germany) containing sheep blood $5 \%$ and incubated at $37^{\circ} \mathrm{C}$ in a $\mathrm{CO}_{2} \quad 5 \%$ enriched atmosphere. Antibiotic sensitivity was tested by a standardised agar diffusion method with commercially available antibiotic-containing disks and checked against the Enterococcus faecalis type strain (ATCC 49474). The antibiotic sensitivity of VRE strains was confirmed by a vancomycin macro-dilution test. Before adding the bacteria to the cell cultures, a single colony was picked and resuspended in RPMI medium (without L-glutamine or L-tryptophan) (Seromed, Berlin). Between 10 and 50 bacteria/well were added to cell cultures. The number of cfu was calculated by serially diluting the bacteria in RPMI medium, plating $10 \mu \mathrm{l}$ of the bacterial suspension on agar plates and counting the colonies after incubation for $18-24 \mathrm{~h}$.

\section{Cell lines and culture}

Iscove's modified Dulbecco's medium and RPMI 1640 (Gibco, Grand Island, NY, USA) with and without Ltryptophan were supplemented with $2 \mathrm{nM}$ L-glutamine and fetal calf serum (FCS) $5 \%$ and used as culture media for the cells. FCS was heat-inactivated at $56^{\circ} \mathrm{C}$ for $45 \mathrm{~min}$ before use. The human uro-epithelial carcinoma cell line RT4 was originally obtained from ATCC (Rockville, MA, USA). The cells were cultured in tissue-culture flasks (Costar, Cambridge, MA, USA) in medium as described above and passaged weekly by detaching the adherent cells with trypsin/EDTA (Gibco). Cells for experiments were harvested with trypsin/EDTA, seeded into wells of a 96-well tissueculture plate (Greiner, Solingen, Germany) at a concentration of $3 \times 10^{4} /$ well and incubated at $37^{\circ} \mathrm{C}$ in a humidified atmosphere enriched with $\mathrm{CO}_{2} 5 \%$.

Table 1. Enterococcal species studied

\begin{tabular}{|c|c|c|c|c|c|c|c|c|c|c|c|}
\hline \multirow{2}{*}{$\begin{array}{l}\text { Isolate } \\
\text { no. }\end{array}$} & \multirow[b]{2}{*}{ Year } & \multirow[b]{2}{*}{ Site } & \multirow{2}{*}{$\begin{array}{l}\text { Clinical } \\
\text { data }\end{array}$} & \multirow[b]{2}{*}{ Species } & \multicolumn{6}{|c|}{ Susceptibility to } & \multirow{2}{*}{$\begin{array}{c}\text { VAN MIC } \\
(\mu \mathrm{g} / \mathrm{ml})\end{array}$} \\
\hline & & & & & AMP & PIP & IMI & CIP & ERY & VAN & \\
\hline 1 & 1998 & Wound & Infection & E. faecium & $\mathrm{R}$ & $\mathrm{R}$ & $\mathrm{R}$ & $M$ & $\mathrm{M}$ & $\mathrm{S}$ & $\cdots$ \\
\hline 2 & 1997 & Stool & Routine & E. faecalis & S & $\mathbf{S}$ & $\mathrm{S}$ & M & $\mathrm{S}$ & $\mathrm{S}$ & $\cdots$ \\
\hline 3 & 1996 & Stool & Routine & E. faecium & $\mathrm{S}$ & $\mathrm{S}$ & M & $\mathrm{R}$ & $\mathrm{R}$ & $\mathrm{R}$ & $>128$ \\
\hline 4 & 1996 & Stool & Routine & E. faecium & $\mathrm{R}$ & $\mathrm{R}$ & $\mathrm{R}$ & $\mathrm{R}$ & $\mathrm{R}$ & $\mathrm{S}$ & $\ldots$ \\
\hline 5 & 1993 & Stool & Routine & E. durans & $S$ & $\mathrm{~S}$ & $\mathrm{~S}$ & $\mathrm{~S}$ & $\mathrm{~S}$ & $\mathrm{R}$ & 128 \\
\hline 6 & 1997 & Subphrenic & Abscess & E. casseliflavus & $\mathrm{R}$ & $\mathrm{R}$ & $\mathrm{R}$ & $\mathrm{R}$ & $\mathrm{R}$ & $\mathrm{R}$ & $>128$ \\
\hline 7 & 1997 & Urine & UTI & E. durans & $S$ & $\mathrm{~S}$ & S & M & $\mathrm{R}$ & $\mathrm{R}$ & $>128$ \\
\hline 8 & 1996 & Stool & Routine & E. faecium & $\mathrm{S}$ & M & $S$ & $\mathrm{R}$ & $\mathbf{S}$ & $\mathrm{R}$ & $>128$ \\
\hline 9 & 1997 & Stool & Routine & E. faecium & S & $\mathrm{S}$ & S & M & $\mathrm{R}$ & $\mathrm{R}$ & $>128$ \\
\hline 10 & 1997 & Stool & Routine & E. faecium & M & $\mathrm{R}$ & M & $\mathrm{R}$ & $\mathbf{R}$ & $\mathrm{R}$ & $>128$ \\
\hline 11 & 1997 & Stool & Routine & E. faecium & $S$ & $\mathrm{~S}$ & $\mathrm{~S}$ & M & $\mathrm{R}$ & $\mathrm{R}$ & $>128$ \\
\hline 12 & 1997 & Stool & Routine & E. faecium & $S$ & M & $\mathrm{R}$ & M & $\mathrm{R}$ & $\mathrm{R}$ & $>128$ \\
\hline 13 & 1997 & Stool & Routine & E. faecium & M & $\mathrm{R}$ & M & $\mathrm{R}$ & $\mathrm{R}$ & $\mathrm{R}$ & $>128$ \\
\hline 14 & 1997 & Anus & BMT & E. casseliflavus & $\mathrm{R}$ & $\mathrm{R}$ & $\mathrm{R}$ & $\mathbf{R}$ & $\mathrm{R}$ & $\mathbf{R}$ & $>128$ \\
\hline 15 & 1994 & Wound & Infection & E. faecium & $\mathrm{R}$ & $\mathrm{R}$ & $\mathrm{R}$ & $\mathrm{R}$ & $\mathrm{R}$ & $\mathrm{S}$ & $\ldots$ \\
\hline
\end{tabular}

Isolate numbers correlate with those used in Fig. 2 and Fig. 4.

$\mathrm{R}$, resistant; M, intermediate sensitivity; S, sensitive; AMP, ampicillin; PIP, piperacillin; IMI, imipenem; CIP, ciprofloxacin; ERY, erythromycin; VAN, vancomycin; MIC, minimal inhibitory concentration; UTI, urinary tract infection; BMT, bone marrow transplantation. 
Stimulation of RT4 cells and infection with bacteria

IFN- $\gamma$ was kindly donated by $\operatorname{Dr} M$. Hündgen (Rentschler, Laupenheim, Germany). RT4 cells in triplicate wells were stimulated with IFN- $\gamma$ at $150 \mathrm{U} / \mathrm{ml}$ or in a 1 to 2 serial dilution starting at $150 \mathrm{U} / \mathrm{ml}$. Cells not stimulated with IFN- $\gamma$ were used as a negative control. The cells were incubated for $96 \mathrm{~h}$, then the bacteria were added. Bacteria were resuspended in RPMI medium without L-glutamine or L-tryptophan to reach an end concentration between 1000 and $5000 \mathrm{cfu} / \mathrm{ml}$ and added to the wells in $10-\mu 1$ volumes, c. 50 bacteria/well; in addition, some cells received L-tryptophan to a final concentration of $100 \mu \mathrm{g} / \mathrm{ml}$ immediately after the inoculation with bacteria. After incubation of cells for $18-24 \mathrm{~h}$, bacterial growth was detected by measuring the optical density at $620 \mathrm{~nm}$. Stimulation of the RT4 cells induces the expression of IDO, which results in the degradation of L-tryptophan. This degradation is almost complete and levels of L-tryptophan are below the detection level of a sensitive HPLC method used in a previous study to measure IDO activity [11]. To prove the relationship between enterococcal growth inhibition and L-tryptophan starvation, some IFN- $\gamma$-stimulated cell cultures were infected with bacteria in medium containing an excess of L-tryptophan, so that the final concentration of L-tryptophan was $100 \mu \mathrm{g} / \mathrm{ml}$.

\section{Assay of IDO induction}

Parallel RT4 cultures were similarly stimulated with IFN- $\gamma$ and after incubation for $96 \mathrm{~h}$ the IDO induction was measured by a method described previously which detects the presence of L-kynurenine [12]. Briefly, $160 \mu 1$ of supernate of the stimulated monocyte-derived macrophages (MDM) were transferred to a V-bottomed 96-well plate (Greiner). Thereafter, $10 \mu 1$ of trichloracetic acid $30 \% \mathrm{v} / \mathrm{v}$ were added and the supernate was incubated at $50^{\circ} \mathrm{C}$ in a water bath for $30 \mathrm{~min}$. The precipitated protein was pelleted by centrifugation at $1800 \mathrm{rpm}$ for $10 \mathrm{~min}$ and then $100 \mu \mathrm{l}$ of the resulting supernate were transferred to a flat-bottomed 96-well plate containing $100 \mu \mathrm{l}$ of Ehrlichs reagent $1.2 \% \mathrm{w} / \mathrm{v}$ in glacial acetic acid (Sigma) per well. The optical density of the resulting yellow colour change was measured by a photometer (SLT Labinstruments, Crailsheim, Germany) at $492 \mathrm{~nm}$.

\section{Northern and Western blot analysis}

RT4 cells were grown in tissue-culture flasks (Costar) and some were stimulated with $400 \mathrm{U}$ of IFN- $\gamma / \mathrm{ml}$ for 16-18 h. Thereafter the cells were washed twice with phosphate-buffered saline (PBS) and total cellular RNA was prepared by guanidinium thiocyanate lysis and ultra-centrifugation according to the method described by Sambrook et al. [13]. RNA (70 $\mu \mathrm{g} / \mathrm{lane})$ was separated on an agarose $0.8 \%$ formaldehyde $6 \%$ gel and transferred to a nylon membrane (Hybond $\mathrm{N}+$, Amersham). The membrane was incubated in Church buffer for $10 \mathrm{~min}$ at $65^{\circ} \mathrm{C}$ and then hybridised with digoxigenin-labelled DNA probes (Boehringer-Mannheim, Germany) specific for glyceraldehyde 3-phosphate dehydrogenase (GAPDH) $(10 \mathrm{ng} / \mathrm{ml})$ and for IDO $(20 \mathrm{ng} / \mathrm{ml})$ overnight at $65^{\circ} \mathrm{C}$. The hybridised labelled probes were detected with the DIG Luminescent Kit for Nucleic Acids from Boehringer-Mannheim following the manufacturer's instructions. The membrane was incubated with the substrate CPD-Star (Boehringer-Mannheim) and then exposed to Kodak $\mathrm{X}$-Omat film to visualise the bands. For Western blot analysis, RT4 cells were stimulated as above and harvested with a cell scraper. The cells were lysed and subjected to electrophoresis on a polyacrylamide $9 \%$ gel under denaturing and reducing conditions. The proteins were transferred to nitrocellulose with a semidry electroblotting apparatus (Phase, Mölln, Germany). The membrane was incubated in skim milk 5\% in PBS for $1 \mathrm{~h}$ at room temperature and thereafter incubated for $1 \mathrm{~h}$ with IDO-specific mouse monoclonal antibodies (kindly given by Osamu Takikawa, University of Wollongong, NSW, Australia). The membrane was washed and then incubated for $1 \mathrm{~h}$ with goat antimouse IgG-horseradish peroxidase conjugated antibodies (Dianova, Hamburg, Germany). Detection was performed with the ECL kit from Amersham and the membrane was exposed to a Kodak X-Omat film.

\section{Results \\ IFN- $\gamma$-induced IDO activity in human uro- epithelial cells}

RT4 cells stimulated with IFN- $\gamma 400 \mathrm{U} / \mathrm{ml}$ were shown to express IDO activity at both the translational and transcriptional level. Fig. 1a shows the detection of IDO-specific mRNA only after stimulation of the cells with IFN- $\gamma$ and no detectable presence of IDO message in unstimulated cells. Also, IDO protein was detected by Western blot of cellular proteins (Fig. 1b), again showing that IDO was present in detectable quantities only after stimulation. The cell culture supernate was also tested for evidence of IDO activity by measuring the concentration of the metabolic product L-kynurenine. The cells stimulated with IFN- $\gamma$ degraded Ltryptophan to L-kynurenine, whereas the unstimulated cells did not, as shown in Fig. 1.

\section{Inhibition of enterococcal growth by RT4 cells}

As can be seen from Fig. 2, unstimulated uro-epithelial cell cultures permitted uninhibited growth of the enterococci, whereas the IFN- $\gamma$-stimulated cells almost completely inhibited the bacterial growth. In Fig. 2 the background $\mathrm{OD}$ of the cell cultures without added bacteria was $c$. 0.145 . This bacteriostatic effect was dose-dependent and, as depicted in Fig. 3, a concentration of IFN- $\gamma$ of $36 \mathrm{U} / \mathrm{ml}$ was sufficient to block 
a

b

$42 \mathrm{kDa}$ -

C

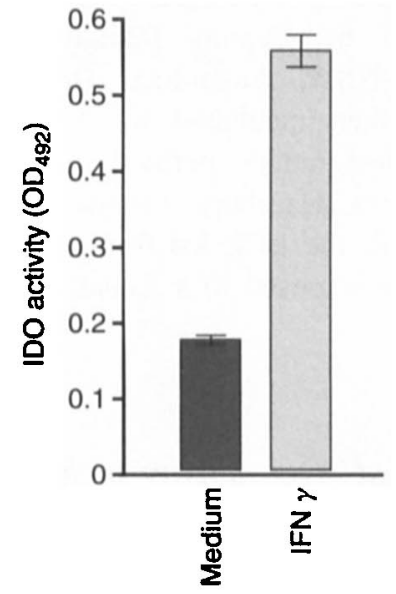

Fig. 1. IFN- $\gamma$-induced IDO expression in RT4 cells. (a) Northern blot analysis showing the detection of IDO and GAPDH mRNA in cells incubated in the presence or absence of IFN- $\gamma$. No IDO mRNA was detected in unstimulated cells (medium). (b) Western blot analysis depicting the detection of the $42-\mathrm{kDa}$ IDO protein in the RT4 cells ( $10 \mu \mathrm{g}$ of protein/lane) stimulated with IFN- $\gamma$. No IDO was detectable in the unstimulated cells. (c) IDO activity, showing measurement of kynurenine content ( $\mathrm{L}$ tryptophan breakdown) in supernate of the same cells as used for the Northern blot (see Materials and methods). The values are means (SD) of triplicate measurements.

enterococcal growth in the cell cultures completely. Fig. 3 shows typical results for isolates representative of the three different enterococcal species most commonly isolated from patients with UTI.

Fig. 2 shows the growth inhibitory effect of the RT4 cells on these multiresistant strains. Both the multiresistant strains and the VRE were equally inhibited by the RT4 cell cultures after stimulation with IFN- $\gamma$. Of the 15 strains shown in Fig. 2, 11 strains were VRE. Thus the uro-epithelial cell line RT4 has a potent

inhibitory effect on the growth of clinical enterococcal isolates that are resistant to all commercially available antibiotics.

Fig. 4 shows that supplementing with L-tryptophan abrogated the growth inhibitory effect of the IFN- $\gamma$ induced IDO, indicating that this effect was due to Ltryptophan depletion. The isolates in Fig. 4 are representative of vancomycin-sensitive and vancomycinresistant isolates.

\section{Discussion}

The innate immune system consists of many components that have either a specialised immune function, such as granulocytes and macrophages, or nonspecialised functions such as the creation of an environment unsuitable for organism adherence, invasion and proliferation. Epithelial cells at the very least present a physical barrier to would-be invading organisms and in addition have a strongly inducible IDO activity [14]. It has been shown that GBS are able to invade epithelial cells and possibly cause disseminated infection via this route $[15,16]$. Enterococci causing a UTI must first adhere to the epithelial surface, where inflammation occurs. Invasion of the cell may lead to dissemination and sepsis [16]. Containment of an infection at this stage has obvious advantages for the host. Recruitment of resident macrophages and dendritic cells results in the release of tumour necrosis factor- $\alpha$, thereby stimulating the local natural killer cells to produce IFN- $\gamma$. This IFN- $\gamma$ would have stimulating effect on the cells at the local site of infection. The epithelial cells stimulated by IFN- $\gamma$ can express IDO and thus degrade both intracellular and extracellular L-tryptophan. There is a substantial body of evidence in the literature to support the role of IDO in host defence against intracellular pathogens such as toxoplasma and chlamydia [14, 17]. A recent study showed that the growth of extracellular organisms can be similarly inhibited by IDO-mediated L-tryptophan degradation in human cord blood macrophages [10]. Bacteria such as GBS can cause sepsis and meningitis in neonates. There are good data to support the local extracellular depletion of L-tryptophan and, for example, low levels of L-tryptophan have been found in cerebrospinal fluid in infection [18]. Enterococci that adhere to the surface epithelium in the urinary tract, and even those that invade and penetrate this cell layer, may be prevented from proliferating by the depletion of the essential amino acid L-tryptophan by the uro-epithelial cells $[16,19]$. This is solely a bacteriostatic effect, but may be sufficient to enable the professional phagocytes and effector cells to be recruited to kill the invading bacteria.

Enterococci are characterised by a greater resistance to antibiotics than other streptococci, they are constitutively resistant to cephalosporins and clindamicin and 


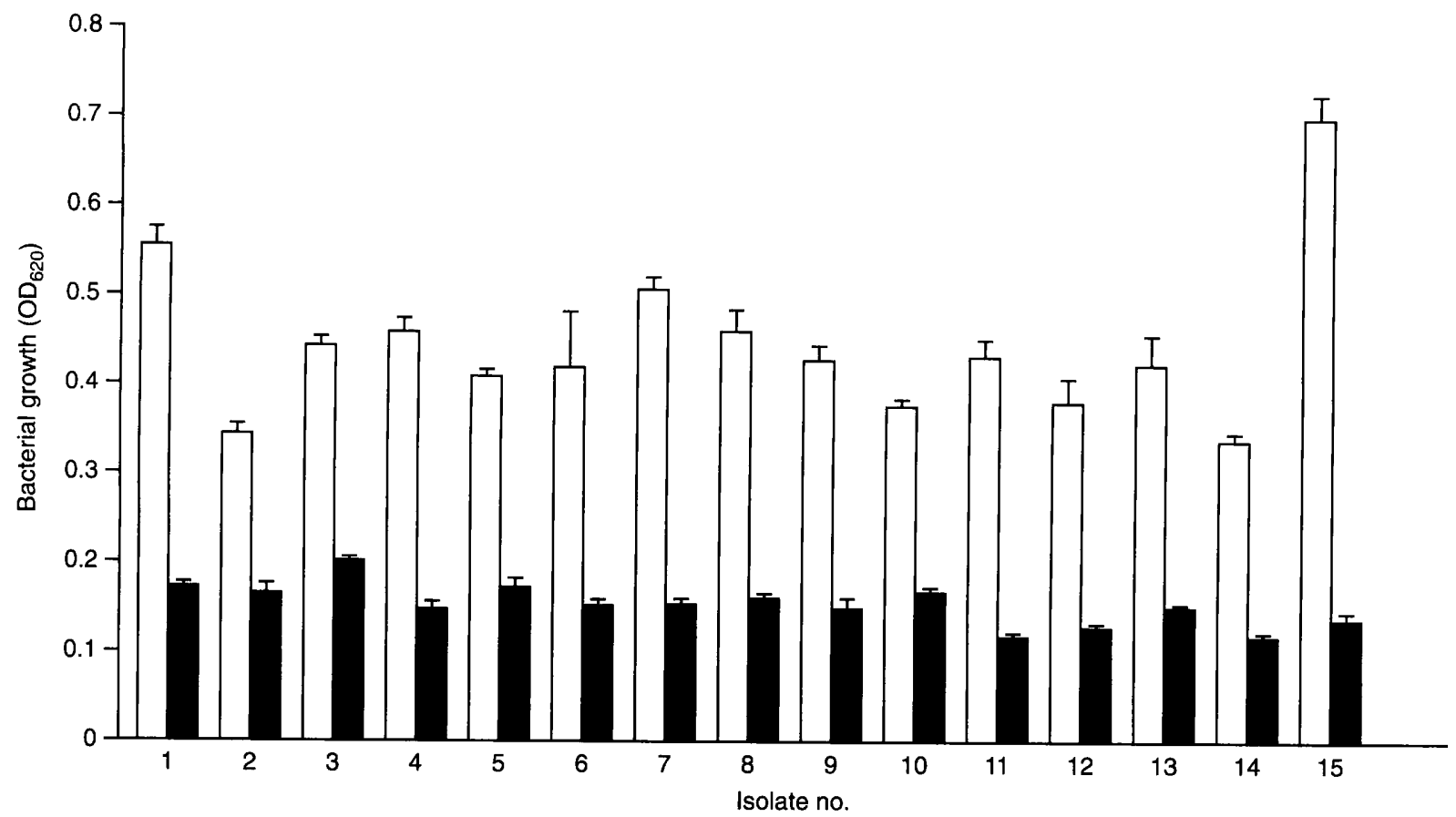

Fig. 2. Growth of multiresistant enterococci inhibited by IFN- $\gamma$ in RT4 cells. Different enterococcal isolates as shown in Table 1 were added to RT4 cells after incubation for $96 \mathrm{~h}$ in the presence ( $\square$ ) or absence ( $\square$ ) of IFN- $\gamma$. Bacterial growth was measured photometrically after $18-24 \mathrm{~h}$. Values are the means (SD) of triplicate cultures.

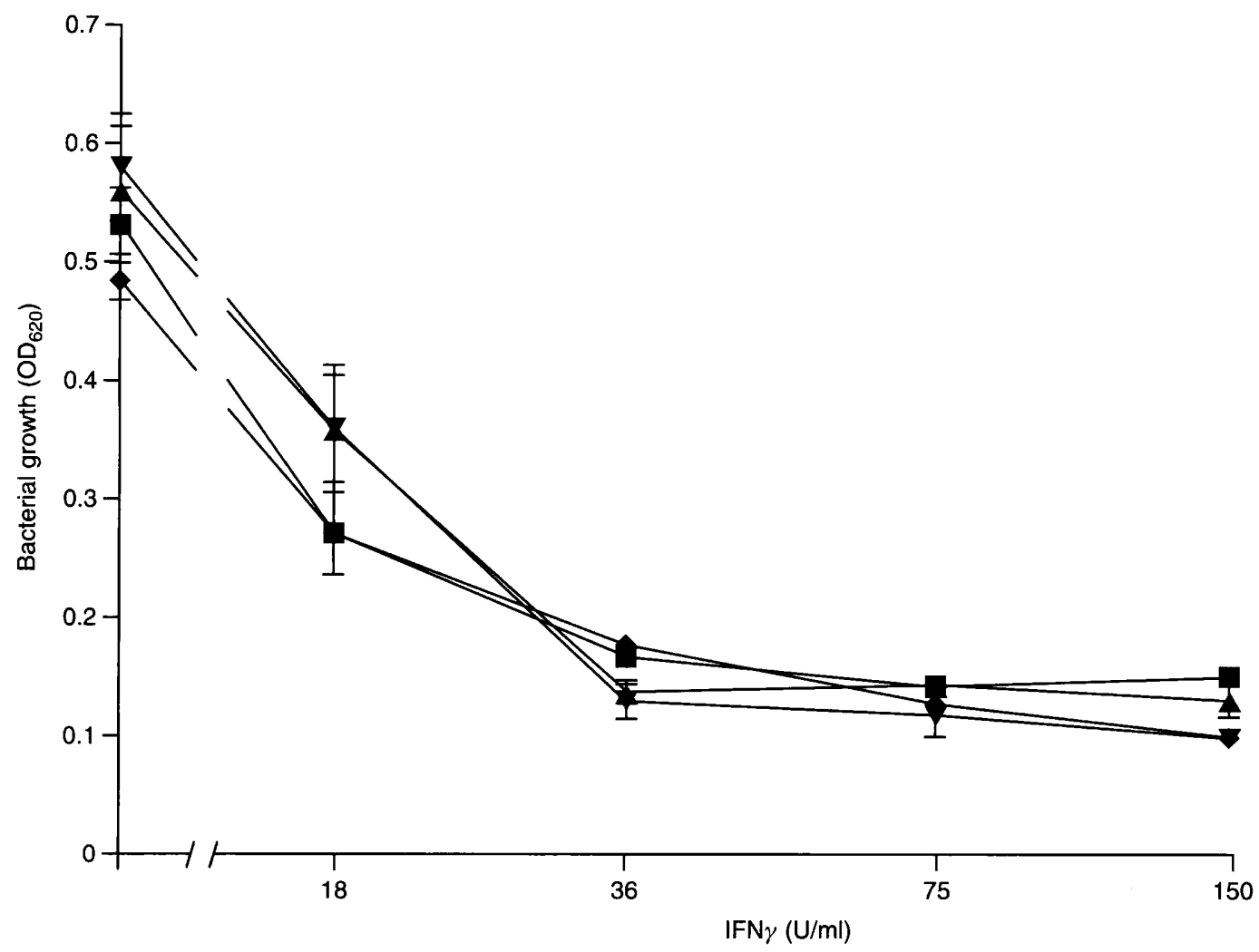

Fig. 3. Dose-dependent IFN- $\gamma$-induced enterococcal growth inhibition in RT4 cells. RT4 cells $\left(3 \times 10^{4} /\right.$ well $)$ were stimulated with varying concentrations of IFN- $\gamma$ and were infected with enterococci $96 \mathrm{~h}$ later. Subsequent bacterial growth was measured photometrically at $620 \mathrm{~nm}$. The enterococci depicted are representative of the different species used: $\mathbf{\square}$. E. faecalis; $\mathbf{\Delta}$, E. casseliflavis; $\mathbf{\nabla}$, E. faecium; $\bullet$ E. durans. Bars represent SD of triplicate values.

some strains, especially the species $E$. faecium, show a wider resistance to $\beta$-lactam antibiotics. Recently, several reports have described clinically relevant strains that were resistant to all commercially available antibiotics [20-23]. Although these strains may turn out to have a reduced virulence compared with susceptible strains, there is no evidence for this to date and fatalities related to these strains have been 


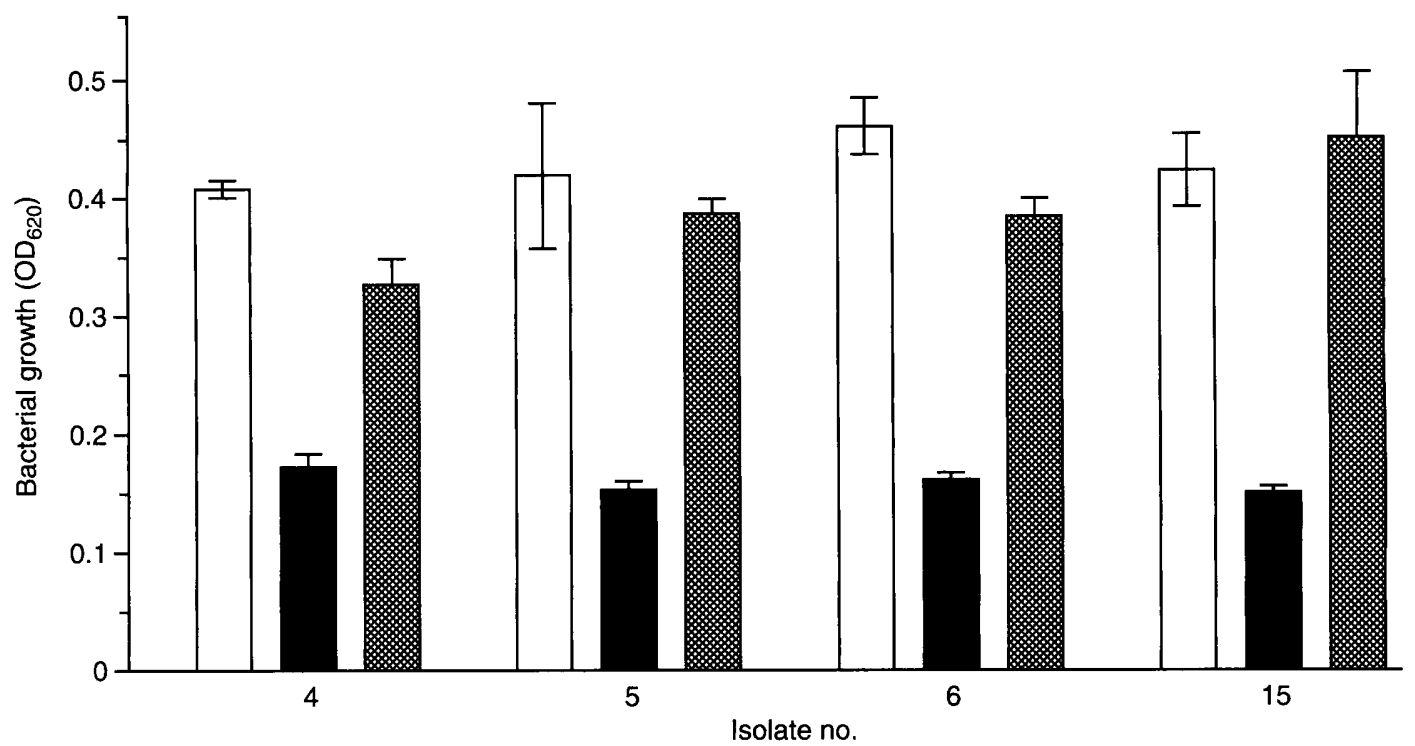

Fig. 4. Enterococcal growth inhibition by RT4 cells due to L-tryptophan starvation. After incubation with ( $\mathbf{m}$, 図) or

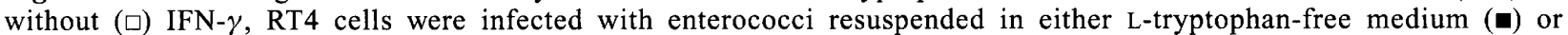

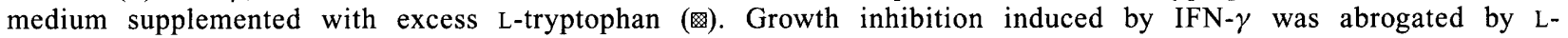
tryptophan supplementation. Representative isolates are depicted and the bacterial growth was measured photometrically. Bars represent SD of triplicate values.

reported [8]. Multiresistant bacteria have a major impact on the morbidity and mortality of hospitalised patients and are also a major cause of increased medical costs [22]. VRE can be isolated from both hospitalised patients and from stools of healthy individuals. In a subgroup of immunosuppressed hospitalised patients, e.g., those undergoing cancer chemotherapy or transplantation, a higher incidence of VRE is observed [1]. This is probably a result of prolonged broad-spectrum antibiotic therapy exerting a selective pressure towards these organisms. Such patients with colonisation of the gut by VRE may also develop infections due to these organisms and it has been reported that bacteraemia with VRE has a poor prognosis [8]. As these patients also generally have a very low leucocyte counts or prolonged aplasia, the effector cells required to eradicate invading bacteria are missing. In this situation the stimulation of the epithelial cells by IFN- $\gamma$ may play a deciding role in the local control of infection, thereby preventing dissemination and bacteraemia. This is perhaps especially true in the subepithelial milieu, as the integrity of the epithelial surface is often reduced by chemotherapy, thus enabling the bacteria to penetrate to the subepithelial tissue more easily. In circumstances such as therapy-induced aplasia, effective treatment of infections with bactericidal antibiotics is a cornerstone of successful management; however, the threat of multidrug resistant bacteria makes this extremely difficult. As colonisation by VRE appears to be far more frequent than dissemination, even in patients with very low leucocyte counts, it is tempting to speculate that growth inhibition caused by the IFN- $\gamma$-induced IDO depletion of L-tryptophan in non-professional immune cells (such as uro-epithelial cells as described here) does in fact have an effect on the local containment of infection, thus preventing bacteraemia and subsequent morbidity. This bacteriostatic effect exerted by nonprofessional phagocytes may represent an important defence system which contains the local numbers of bacteria and thereby prevents or slows down a possible disseminated infection.

We would like to thank Claudia Oberdörfer for excellent technical assistance and Dr Sabine Krämer for providing us with the VRE isolates. This work was supported by grants from the German Research Society (DFG) to W.D. and from the University Research Committee to C.M.

\section{References}

1. Suppola JP, Volin L, Valtonen VV, Vaara M. Overgrowth of Enterococcus faecium in the feces of patients with hematologic malignancies. Clin Infect Dis 1996; 23: 694-697.

2. Montecalvo MA, Shay DK, Patel $\mathrm{P}$ et al. Bloodstream infections with vancomycin-resistant enterococci. Arch Intern Med 1996; 156: 1458-1462.

3. Sastry V, Brennan PJ, Levy MM et al. Vancomycin-resistant enterococci: an emerging pathogen in immunosuppressed transplant recipients. Transplant Proc 1995; 27: 954-955.

4. Endtz HP, van den Braak N, van Belkum A et al. Fecal carriage of vancomycin-resistant enterococci in hospitalized patients and those living in the community in The Netherlands. $J$ Clin Microbiol 1997; 35: 3026-3031.

5. Witte W. Impact of antibiotic use in animal feeding on resistance of bacterial pathogens in humans. Ciba Found Symp 1997; 207: 61-71.

6. Stosor V, Peterson LR, Postelnick M, Noskin GA. Enterococcus faecium bacteremia: does vancomycin resistance make a difference? Arch Intern Med 1998; 158: 522-527.

7. Lucas GM, Lechtzin N, Puryear DW, Yau LL, Flexner CW, Moore RD. Vancomycin-resistant and vancomycin-susceptible enterococcal bacteremia; comparison of clinical features and outcomes. Clin Infect Dis 1998; 26: 1127-1133.

8. Linden PK, Pasculle AW, Manez $\mathrm{R}$ et al. Differences in outcomes for patients with bacteremia due to vancomycinresistant Enterococcus faecium or vancomycin-susceptible $E$. faecium. Clin Infect Dis 1996; 22: 663-670.

9. Pfefferkorn ER, Rebhun S, Eckel M. Characterization of an 
indoleamine 2,3-dioxygenase induced by gamma-interferon in cultured human fibroblasts. J Interferon Res 1986; 6: 267-279.

10. MacKenzie $C R$, Hadding $U$, Däubener W. Interferon-gammainduced activation of indoleamine 2,3-dioxygenase in cord blood monocyte-derived macrophages inhibits the growth of group B streptococci. J Infect Dis 1998; 178: 875-878.

11. MacKenzie CR, Willberg CB, Däubener W. Inhibition of group B streptococcal growth by IFN gamma-activated human glioblastoma cells. J Neuroimmunol 1998; 89: 191-197.

12. Däubener W, Wanagat N, Pilz K, Seghrouchni S, Fischer HG, Hadding U. A new, simple, bioassay for human IFN-gamma. J Immunol Methods 1994; 168: 39-47.

13. Sambrook J, Fritsch EF, Maniatis T. Molecular cloning: a laboratory manuel, 2nd edn. Cold Spring Harbor, NY, Cold Spring Harbor Laboratory Press. 1998: 7.3-7.23.

14. Byrne GI, Lehmann LK, Landry GJ. Induction of tryptophan catabolism is the mechanism for gamma-interferon-mediated inihibition of intracellular Chlamydia psittaci replication in T24 cells. Infect Immun 1986; 53: 347-351.

15. Nizet V, Kim KS, Stins $M$ et al. Invasion of brain microvascular endothelial cells by group B streptococci. Infect Immun 1997; 65: 5074-5081.

16. Winram SB, Jonas M, Chi E, Rubens CE. Characterization of group B streptococcal invasion of human chorion and amnion epithelial cells in vitro. Infect Immun 1998; 66: 4932-4941.

17. Pfefferkorn ER. Interferon gamma blocks the growth of Toxoplasma gondii in human fibroblasts by inducing the host cells to degrade tryptophan. Proc Natl Acad Sci USA 1984; 81: 908-912.

18. Gisslén M, Larsson M, Norkrans G, Fuchs D, Wachter H, Hagberg L. Tryptophan concentrations increase in cerebrospinal fluid and blood after zidovudine treatment in patients with HIV type 1 infection. AIDS Res Hum Retroviruses 1994; 10: 947-951.

19. Yao L, Bengualid V, Lowy FD, Gibbons JJ, Hatcher VB, Berman JW. Internalization of Staphylococcus aureus by endothelial cells induces cytokine gene expression. Infect Immun 1995; 63: 1835-1839.

20. Wade JJ, Rolando N, Williams R, Casewell MW. Serious infections caused by multiply-resistant Enterococcus faecium. Microb Drug Resist 1995; 1: 241-243.

21. Jones RN, Sader HS, Erwin ME, Anderson SC. Emerging multiply resistant enterococci among clinical isolates. I. Prevalence data from 97 medical center surveillance study in the United States. Enterococcus Study Group. Diagn Microbiol Infect Dis 1995; 21: 85-93.

22. Handwerger S, Raucher B, Altarac D et al. Nosocomial outbreak due to Enterococcus faecium highly resistant to vancomycin, penicillin, and gentamicin. Clin Infect Dis 1993; 16: $750-755$.

23. Stroud L, Edwards J, Danzing L, Culver D, Gaynes R. Risk factors for mortality associated with enterococcal bloodstream infections. Infect Control Hosp Epidemiol 1996; 17: 576-580. 